\title{
Pengaruh perbedaan jenis pelarut dalam proses ekstraksi buah mengkudu (Morinda citrifolia L.) pada pakan terhadap viabilitas protozoa dan produksi gas in-vitro
}

\author{
Deni Ramdani, Marjuki dan Siti Chuzaemi \\ Departemen Nutrisi dan Makanan Ternak, Fakultas Peternakan Universitas Brawijaya \\ Jl. Veteran, Malang (65145) - Indonesia
}

Correspondent author: dr.ramdani93@gmail.com

\begin{abstract}
The aim of this study is to determine the best solvent for noni fruits (Morinda citrifolia L.) extraction processes to reduce ruminal protozoa's growth and gas production. This research used nested on randomized block design with two factors of treatment and three group replication, if there was significant different would be tested by Duncan's Multiple Range Test Methods. EM was noni fruits extract which methanol used as solvent, and EA was noni fruits extract which aquadest used as solvent. The result showed protozoa and gas production were decreased on additional of noni fruits extract with methanol solvent $(\mathrm{P}<0.05)$. The conclusion is the methanol can be used as the best solvent in noni fruits extraction processes to reduce ruminal protozoa and to increase degradability.
\end{abstract}

Keywords: Saponin, defaunation, gass, protozoa, viability

\section{PENDAHULUAN}

Ternak ruminansia merupakan salah satu ternak yang mengkonsumsi hijauan sebagai pakan utama dan dijadikan sebagai sumber energi untuk kebutuhan hidup pokok dan produksinya. Rumen sebagai salah satu organ pencernaan yang dimiliki ternak ruminansia, merupakan habitat alami dan istimewa bagi mikroba dalam melakukan berbagai macam aktivitas pencernaan pakan secara fermentatif. Ternak ruminansia tanpa adanya mikroba tidak akan mampu mencerna bahan pakan berserat kasar tinggi dan dijadikan sebagai sumber energi (Lamid dkk., 2011).

Mikroba rumen mampu memanfaatkan dan memecah berbagai ikatan kompleks dalam pakan sehingga ketersediaan nutrisi bagi ternak mampu meningkatkan produksi. Rumen memiliki kondisi yang ideal bagi pertumbuhan mikroba termasuk protozoa. Protozoa yang memiliki sifat kanibal diharapkan dapat ditekan pertumbuhannya sehingga tidak memakan bakteri dalam rumen.

Buah mengkudu (Morinda citrifolia L.) memiliki kandungan senyawa alkaloid, fenol, flavonoid, glikosida, antrakuinon dan kumarin (Valli and Murugalakshmi, 2014). Buah mengkudu juga mengandung senyawa antrakuinon, skopoletin dan saponin (Satwadhar et al., 2011). Selain komponen flavonoid buah mengkudu, juga mengandung vitamin $\mathrm{A}, \mathrm{C}$, niasin, tiamin, ribovlafin serta mineral seperti zat besi, kalium, natrium dan kalsium.

Saponin merupakan salah satu senyawa yang berfungsi sebagai agen defaunator untuk mengurangi jumlah protozoa di dalam cairan rumen. Perbedaan konsentrasi senyawa saponin dalam ekstrak buah mengkudu secara 
kuantitatif ditentukan oleh kemampuan jenis pelarut yang digunakan dalam proses ekstraksi untuk melarutkan senyawa saponin. Berdasarkan uraian tersebut, perlu dilakukan penelitian lebih lanjut yang bertujuan untuk mengetahui pengaruh perbedaan jenis pelarut dalam proses ekstraksi buah mengkudu pada pakan terhadap produksi gas in-vitro, populasi protozoa dan persentase viabilitas protozoa rumen secara in-vitro.

\section{MATERI DAN METODE}

Penelitian ini dilaksanakan pada bulan Juni sampai Agustus 2015. Pembuatan ekstrak buah mengkudu dilakukan di Laboratorium (Lab.) Biokimia Pangan Fakultas Teknologi Pertanian Universitas Brawijaya (UB). Percobaan produksi gas secara in-vitro dilakukan di Lab. Nutrisi dan Makanan Ternak UB. Perhitungan jumlah dan viabilitas protozoa rumen dilaksanakan di Lab. Mikrobiologi dan Lab. Epidemiologi Fakultas Peternakan UB.

Materi yang digunakan dalam penelitian ini adalah buah mengkudu matang yang baru dipetik dari pohonnya; bahan pakan terdiri dari campuran rumput gajah dan pollard dengan kandungan Protein Kasar (PK) masing-masing 9\% dan $17 \%$ dari Bahan kering (BK); cairan rumen dari sapi betina berfistula yang berumur 8 tahun yang diberi pakan berupa rumput gajah dan campuran antara pollar, bekatul dan bungkil kelapa yang diambil pada pagi hari sebelum pemberian pakan; seperangkat bahan kimia untuk pengukuran produksi gas in-vitro; seperangkat bahan kimia untuk perhitungan populasi dan viabilitas protozoa rumen, dan; pelarut yang digunakan adalah metanol dan akuades.
Inkubasi selama 48 jam pada suhu $39^{\circ} \mathrm{C}$ anaerob untuk pengukuran produksi gas dilakukan menggunakan syringe berskala; inkubasi selama 48 jam pada suhu $39^{\circ} \mathrm{C}$ anaerob untuk pengukuran populasi dan viabilitas protozoa rumen dilakukan menggunakan tabung in-vitro. Metode yang digunakan adalah percobaan laboratorium menggunakan rancangan acak kelompok pola tersarang 2 faktor, masing-masing dilakukan 3 kali running sebagai ulangan sebagai berikut:

$\mathrm{EA}=$ Ekstrak akuades buah mengkudu

$$
\begin{aligned}
& \mathrm{L} 0=\text { tanpa penambahan ekstrak } \\
& \mathrm{L} 1=+ \text { Ekstrak } 1 \% \text { BK pakan } \\
& \mathrm{L} 2=+ \text { Ekstrak } 2 \% \text { BK pakan } \\
& \mathrm{L} 3=+ \text { Ekstrak } 3 \% \text { BK pakan }
\end{aligned}
$$

$\mathrm{EM}=$ Ekstrak methanol buah mengkudu

$$
\begin{aligned}
\mathrm{L} 0 & =\text { tanpa penambahan ekstrak } \\
\mathrm{L} 1 & =+ \text { Ekstrak } 1 \% \text { BK pakan } \\
\mathrm{L} 2 & =+ \text { Ekstrak } 2 \% \text { BK pakan } \\
\mathrm{L} 3 & =+ \text { Ekstrak 3\% BK pakan } \\
& \text { Variabel yang diamati meliputi }
\end{aligned}
$$
produksi gas total in-vitro menurut Makkar et al., (1995), potensi produksi gas (b) dan laju produksi gas (c) yang ditentukan berdasarkan persamaan Mertans (1977) yang dikutip oleh Makkar et al., (1995), populasi dan viabilitas protozoa rumen dan dinamika pertumbuhan protozoa rumen yang dihitung dan dimodifikasi berdasarkan petunjuk Ogimoto et al., (1981). Analisis data menggunakan analisis ragam untuk mengukur produksi gas dan viabilitas protozoa rumen, serta analisis peragam untuk perhitungan populasi protozoa rumen. Uji Jarak Berganda Duncan digunakan untuk mengetahui perbedaan masing-masing perlakuan.

\section{HASIL DAN PEMBAHASAN}


Tabel 1. Kandungan nutrisi bahan pakan untuk pakan percobaan

\begin{tabular}{lcccccc}
\hline \multirow{2}{*}{ Bahan Pakan } & $\begin{array}{c}\text { Bahan }^{1} \\
\text { Kering }^{1}(\%)\end{array}$ & $\mathrm{BO}^{1}$ & $\mathrm{PK}^{1}$ & LK & SK & BETN \\
\cline { 2 - 6 } Rumput Gajah & 16,46 & 89,06 & 8,12 & $2,7^{2}$ & $44,49^{2}$ & $23,16^{2}$ \\
Pollard & 82,31 & 94,62 & 17,06 & $6,92^{3}$ & $3,75^{3}$ & $65,88^{3}$ \\
\hline
\end{tabular}

Sumber: ${ }^{1}$ Hasil analisis laboratorium Nutrisi dan Makanan Ternak Fakultas Peternakan Universitas Brawijaya (2015); ${ }^{2}$ Dinata, dkk. (2015); ${ }^{3}$ Rianto, dkk. (2006)

\section{Gambaran umum penelitian}

Substrat yang digunakan dalam penelitian ini terdiri dari campuran antara rumput gajah (Pennisetum purpureum) dan pollard (Triticum aestivum) dalam bentuk tepung. Kandungan nutrisi rumput gajah dan pollard sebagai pakan percobaan disajikan pada Tabel 1. Berdasarkan hasil analisis laboratorium diperoleh kandungan protein kasar (PK) rumput gajah sebesar $8 \%$ dan kandungan PK pollard sebesar $17 \%$ dari total bahan kering masing-masing bahan pakan.

Data kandungan protein kasar kedua bahan pakan dijadikan sebagai acuan dalam penyusunan pakan percobaan. Proses penyusunan pakan percobaan menggunakan metode perhitungan pearson square sehingga pakan percobaan memiliki kandungan protein kasar sebesar $12 \%$ sesuai NRC (2001), bahwa kebutuhan protein kasar ternak ruminansia berkisar antara 9$15 \%$ dari BK pakan tergantung status fisiologis ternak. Berdasarkan hasil perhitungan menggunakan metode pearson square, proporsi rumput gajah dan pollard dalam pakan percobaan berturut-turut adalah $56,59 \%$ dan $43,41 \%$.

Bahan organik dalam pakan yang telah mengalami degradasi oleh mikroba rumen akan dikonversi menjadi produk akhir berupa energi hasil degradasi komponen karbohidrat dan ammonia $\left(\mathrm{NH}_{3}\right)$ yang merupakan produk hasil degradasi fraksi protein atau sumber nitrogen lain yang bukan berasal dari protein (non protein nitrogen). Degradasi bahan organik pakan oleh mikroba juga menghasilkan produk sekunder berupa Volatile Fatty Acid (VFA) dan berbagai macam gas seperti karbon dioksida $\left(\mathrm{CO}_{2}\right)$, hidrogen $\left(\mathrm{H}_{2}\right)$, metana $\left(\mathrm{CH}_{4}\right)$ dan gas lainnya sebagaimana diungkapkan oleh Kurniawati (2009).

Semakin tinggi kandungan bahan organik yang mampu didegradasi oleh mikroba, maka jumlah gas yang dihasilkan akan semakin meningkat. Pengukuran produksi gas dilakukan dengan menggunakan teknik in-vitro dalam syringe berskala. Pemilihan teknik ini didasarkan pada tingkat efisiensi dan efektifitas kerja dengan hasil yang cukup mendekati dengan hasil penelitian jika dilakukan secara invivo (Menke et al., 1979).

\section{Pengaruh perlakuan terhadap populasi protozoa rumen}

Hasil analisis peragam menunjukkan bahwa penggunaan metanol sebagai pelarut memberikan pengaruh yang berbeda $(\mathrm{P}<0,05)$ dalam menurunkan populasi protozoa rumen. Jumlah populasi protozoa rumen pada perlakuan penambahan ekstrak buah mengkudu dengan pelarut methanol dan akuades dapat diamati pada tabel 2 . Berdasarkan analisis peragam, diperoleh hasil bahwa penggunaan metanol sebagai bahan pelarut dalam proses ekstraksi buah mengkudu memberikan pengaruh yang lebih baik dibandingkan dengan akuades.

Tabel 2. Populasi protozoa rumen 


\begin{tabular}{cc}
\hline Jenis Pelarut & $\begin{array}{c}\text { Populasi protozoa } \\
\text { rumen }(\log \text { sel/ ml })\end{array}$ \\
\hline Akuades & $7,16 \pm 0,16^{\mathrm{a}}$ \\
Metanol & $7,11 \pm 0,16^{\mathrm{b}}$ \\
\hline
\end{tabular}

Keterangan:

a-b superscript yang berbeda pada kolom yang sama menunjukkan perbedaan nyata $(\mathrm{P}<0,05)$ antar perlakuan

Penelitian sebelumnya yang
dilakukan oleh Rosida (2002),
menunjukkan bahwa penggunaan
larutan metanol sebagai pelarut dalam
proses ekstraksi suatu bahan,
memberikan hasil yang lebih baik
dibandingkan dengan hasil ekstraksi
akuades.
Buah mengkudu memiliki
kandungan metabolit sekunder berupa senyawa aktif saponin yang mampu membunuh dan menurunkan populasi protozoa. Jumlah rata-rata populasi protozoa terendah terdapat pada perlakuan penambahan ekstrak buah mengkudu dengan larutan metanol sebagai pelarut yaitu sebesar 7,11 $\pm 0,16$ $\log \mathrm{sel} / \mathrm{ml}$ atau senilai dengan 1,28 x $10^{7} \mathrm{sel} / \mathrm{ml}$ cairan rumen. Rata-rata populasi protozoa pada pemberian ekstrak buah mengkudu dengan menggunakan pelarut akuades adalah $7,16 \pm 0,16 \log \mathrm{sel} / \mathrm{ml}$ atau senilai dengan $1,44 \times 10^{7} \mathrm{sel} / \mathrm{ml}$ cairan rumen. Populasi protozoa dalam penelitian ini lebih tinggi dibandingkan dengan populasi protozoa rumen yang dilaporkan oleh Hungate (1966) yang berkisar antara $10^{5}-10^{6} \mathrm{sel} / \mathrm{ml}$ cairan rumen.

Penurunan populasi protozoa diakibatkan oleh senyawa saponin yang berikatan dengan komponen sterol pada membran sel protozoa yang mampu merusak tegangan permukaan membran serta menyebabkan sel berpori dan akhirnya lisis. Kondisi ini disebabkan karena senyawa saponin terekstrak lebih baik dalam larutan metanol.

Metanol merupakan suatu senyawa yang memiliki struktur molekul $\mathrm{CH}_{3} \mathrm{OH}$, bersifat polar karena memiliki gugus hidroksil (-OH) dan juga bersifat non-polar karena memiliki gugus metil $\left(-\mathrm{CH}_{3}\right)$. Walaupun demikian, metanol merupakan senyawa bersifat sangat polar, sebagaimana dinyatakan oleh Lazuardi (2006). Saponin dapat diekstrak secara baik dengan menggunakan pelarut metanol dengan konsentrasi lebih dari $40 \%$ (Oleszek, 2000). Hasil penelitian ini sesuai dengan penelitian terdahulu yang dilakukan oleh Herdian, dkk. (2011).

\section{Pengaruh perlakuan terhadap jumlah protozoa hidup}

Berdasarkan hasil analisis peragam menunjukkan bahwa perbedaan jenis pelarut dalam proses ekstraksi buah mengkudu tidak memberikan pengaruh nyata terhadap jumlah protozoa hidup $(\mathrm{P}>0,05)$, namun memberikan pengaruh nyata terhadap persentase viabilitas protozoa $(\mathrm{P}<0,05)$. Jumlah protozoa hidup dan persentase viabilitas protozoa antara perlakuan dapat dilihat pada Tabel 3.

Tabel 3. Persentase viabilitas protozoa

\begin{tabular}{ccc}
\hline $\begin{array}{c}\text { Jenis } \\
\text { Pelarut }\end{array}$ & $\begin{array}{c}\text { Protozoa hidup } \\
(\log \mathrm{sel} / \mathrm{ml})\end{array}$ & $\begin{array}{c}\text { Viabilitas } \\
\text { protozoa }(\%)\end{array}$ \\
\hline $\begin{array}{c}\text { Aquadest } \\
\text { Metanol }\end{array}$ & $6,98 \pm 0,19$ & $68,05 \pm 9,87^{\mathrm{a}}$ \\
\hline Ken & 6,17 & $65,75 \pm 10,06^{\mathrm{b}}$ \\
\hline
\end{tabular}

Keterangan:

a-b superscript yang berbeda pada kolom yang sama menunjukkan perbedaan nyata $(\mathrm{P}<0,05)$ antar perlakuan

Rata-rata jumlah protozoa hidup terkecil adalah $6,92 \pm 0,17 \log \mathrm{sel} / \mathrm{ml}$ atau senilai dengan $8,32 \times 10^{6} \mathrm{sel} / \mathrm{ml}$ cairan rumen. Jumlah ini merupakan jumlah protozoa hidup pada 
penambahan ekstrak buah mengkudu dengan menggunakan pelarut metanol. Rata-rata jumlah protozoa hidup pada penambahan ekstrak buah mengkudu dengan menggunakan akuades sebagai pelarut adalah $6,98 \pm 0,19 \mathrm{log} \mathrm{sel} / \mathrm{ml}$ atau sekitar $9,55 \times 10^{6} \mathrm{sel} / \mathrm{ml}$ cairan rumen.

Data jumlah protozoa yang hidup tidak dijadikan sebagai acuan dalam menentukan tinggi rendahnya kemampuan pelarut untuk melarutkan senyawa saponin dalam buah mengkudu, tetapi hanya memberikan gambaran jumlah protozoa hidup dalam satuan waktu tertentu. Parameter utama yang memberikan gambaran kemampuan metanol dan akuades dalam proses ekstraksi adalah parameter persentase viabilitas protozoa.

\section{Pengaruh perlakuan terhadap persentase viabilitas protozoa}

Viabilitas atau daya hidup protozoa diartikan sebagai jumlah protozoa yang mampu bertahan hidup setelah ditambahakan perlakuan. Protozoa yang hidup dan yang mati dapat dibedakan melalui prosedur pewarnaan. Protozoa hidup masih memiliki membran sel yang berfungsi dengan baik dan tidak menyerap warna, sedangkan protozoa mati cederung menyerap warna diakibatkan rusaknya membran sel akibat pengaruh senyawa saponin yang berikatan dengan senyawa sterol disebagian sisi permukaannya. Nilai persentase viabilitas protozoa rumen terhadap jenis pelarut yang berbeda dapat dilihat pada Tabel 3 .

Rata-rata persentase viabilitas protozoa rumen yang terkecil adalah $65,75 \pm 10,06 \%$ dengan metanol sebagai pelarut, sedangkan rata-rata persentase viabilitas protozoa rumen dengan pemberian ekstrak buah mengkudu menggunakan pelarut akuades adalah $68,05 \pm 9,87 \%$. Daya tahan protozoa terhadap ekstrak metanol buah mengkudu lebih rendah, artinya kandungan saponin terlarut dalam ekstrak metanol buah mengkudu lebih tinggi dibandingkan saponin dalam ekstrak akuades buah mengkudu.

Hasil penelitian menunjukkan bahwa pelarut metanol merupakan pelarut terbaik yang bisa digunakan dalam proses ekstraksi. Metanol dikenal sebagai pelarut universal. Astarina, dkk. (2013), menyatakan bahwa gugus hidroksil dan metil pada metanol memberikan kecenderungan menarik analit-analit yang bersifat polar maupun nonpolar. Oleszek (2000), mengungkapkan bahwa saponin merupakan senyawa glikosida yang tersusun atas dua jenis molekul sebagai kerangka utama yaitu kerangka steroid atau triterpenoid yang bersifat nonpolar serta memiliki gugus hidroksil yang mampu berikatan dengan gula sederhana yang bersifat polar, sehingga saponin mampu terlarut lebih baik didalam pelarut metanol.

Saponin yang terlarut akan berikatan dengan sterol yang terdapat pada membran sel protozoa dan menyebabkan kematian sel. Semakin tinggi jumlah senyawa saponin terlarut dalam ekstrak, maka semakin rendah jumlah protozoa yang mampu bertahan hidup yang ditandai dengan nilai persentase viabilitas protozoa rumen yang semakin rendah.

\section{Pengaruh perlakuan terhadap produksi gas total secara in-vitro}

Hasil perhitungan produksi gas total secara in-vitro yang diberi ekstrak buah mengkudu dengan jenis pelarut yang berbeda, tersaji pada Tabel 4 . Rata-rata produksi gas pada pemberian ekstrak buah mengkudu menggunakan metanol dan akuades sebagai pelarut secara berturut-turut yaitu $163,84 \pm 9,11$ dan 167,33 $\pm 9,74 \mathrm{ml} / 500 \mathrm{mg}$ BK pakan. 
Hasil analisis ragam menunjukkan bahwa perlakuan yang dicobakan terhadap produksi gas berbeda nyata antar perlakuan $(\mathrm{P}<0,05)$.

Tabel 4. In-vitro Produksi gas total

\begin{tabular}{cc}
\hline $\begin{array}{c}\text { Jenis } \\
\text { pelarut }\end{array}$ & $\begin{array}{c}\text { Rata-rata produksi gas total } \\
(\mathrm{ml} / 500 \mathrm{mg} \mathrm{BK})\end{array}$ \\
\hline Akuades & $167,33 \pm 9,74^{\mathrm{a}}$ \\
Metanol & $163,84 \pm 9,11^{\mathrm{b}}$ \\
\hline
\end{tabular}

Keterangan:

a-b superscript yang berbeda pada kolom yang sama menunjukkan perbedaan nyata $(\mathrm{P}<0,05)$ antar perlakuan

Produksi gas erat kaitannya dengan nilai degradasi bahan organik pakan oleh mikroba dalam cairan rumen. Semakin tinggi populasi mikroba dalam cairan rumen, maka semakin tinggi pula bahan organik pakan yang mampu didegradasi dan gas yang dihasilkan akan semakin meningkat. Tinggi dan rendahnya populasi mikroba rumen dalam hal ini adalah bakteri, salah satunya dipengaruhi oleh jumlah protozoa hidup didalam rumen. Protozoa akan memakan bakteri atau protozoa lain yang berukuran lebih kecil untuk mencukupi kebutuhan asam amino dan senyawa lain pembentuk sel. Semakin tinggi jumlah sel protozoa dalam cairan rumen, maka populasi bakteri rumen semakin rendah. Semakin rendah populasi bakteri dalam cairan rumen maka aktivitas degradasi yang ditandai dengan produksi gas akan semakin rendah.

Perbedaan komponen kimia gas yang dihasilkan oleh mikroba sangat tergantung dari jenis pakan dan jenis mikroba yang mendegradasinya. Fraksi gas yang paling banyak dihasilkan oleh mikroba rumen adalah gas $\mathrm{CO}_{2}$. Arora (1995), menerangkan bahwa gas yang dihasilkan dalam cairan rumen selama proses fermentasi terdiri dari $\mathrm{CO}_{2} 63$ $65 \%, \mathrm{CH}_{4}$ 27-29\%, $\mathrm{N}_{2}$ sebanyak 6,7\%, $\mathrm{H}_{2} \mathrm{~S}+\mathrm{H}_{2}$ sebanyak $2,3 \%$ dan gas $\mathrm{O}_{2}$ sebanyak $1 \%$. Gas $\mathrm{CH}_{4}$ terbentuk oleh bakteri metanogen yang bersimbiosis dengan protozoa. Semakin tinggi jumlah protozoa yang hidup dalam cairan rumen, maka semakin tinggi pula gas $\mathrm{CH}_{4}$ yang dihasilkan.

Jumlah saponin terlarut yang lebih tinggi dalam ekstrak metanol buah mengkudu, mengakibatkan jumlah protozoa semakin menurun yang berakibat pada menurunnya produksi gas $\mathrm{CH}_{4}$ sebagai akibat berkurangnya simbiosis antara protozoa dan bakteri metanogen untuk menghasilkan $\mathrm{CH}_{4}$. Wahyuni, dkk. (2014), menyatakan bahwa protozoa merupakan inang bagi sebagian bakteri metanogen yang memanfaatkan gas $\mathrm{H}_{2}$ sebagai substrat untuk pembentukan $\mathrm{CH}_{4}$ dengan bantuan $\mathrm{CO}_{2}$. Berkurangnya kadar $\mathrm{CH}_{4}$ berdampak positif bagi ternak, hal ini dikarenakan $\mathrm{CH}_{4}$ merupakan ukuran tidak efisiennya penggunaan energi oleh ternak.

Penurunan jumlah protozoa berkorelasi positif terhadap penurunan kadar gas $\mathrm{CH}_{4}$ yang dihasilkan oleh mikroba. Sebagaimana dinyatakan oleh Thalib, dkk. (2004), bahwa adanya hubungan yang sebanding antara populasi protozoa dalam cairan rumen dengan produksi gas metana. Artinya, jika populasi protozoa semakin rendah maka produksi gas metana juga semakin rendah.

\section{Pengaruh perlakuan terhadap potensi produksi gas (b) dan laju produksi gas (c)}

Hasil analisis ragam menunjukkan bahwa penggunaan metanol sebagai bahan pelarut dalam proses ekstraksi buah mengkudu tidak memberikan pengaruh yang berbeda 
$(\mathrm{P}>0,05)$ terhadap nilai potensi produksi gas (nilai b) dibandingkan dengan pemberian ekstrak aquadest buah mengkudu. Gambar 1 menunjukkan bahwa rata-rata nilai $b$ pada pemberian ekstrak metanol buah mengkudu yaitu $193,11 \pm 7,05 \mathrm{ml} / 500 \mathrm{mg}$ BK pakan, sedangkan rata-rata nilai $b$ pada pemberian ekstrak akuades buah mengkudu sebesar 193,56 $\pm 13,73 \mathrm{ml} /$ 500 mg BK pakan.

Nilai rata-rata potensi produksi gas (b) merupakan parameter potensi bahan organik yang tidak larut dalam cairan rumen namun mampu terdegradasi oleh mikroba rumen. Nilainilai parameter degradasi terdiri atas nilai a, b dan c yang dihitung melalui persamaan Ørskov et al. (1979) yaitu Y $=\mathrm{a}+\mathrm{b}\left(1-\mathrm{e}^{-\mathrm{ct}}\right)$. Nilai a dalam penelitian ini tidak dibahas karena secara biologi, nilai produksi gas pada saat waktu inkubasi 0 jam $(\mathrm{t}=0)$ adalah 0 .

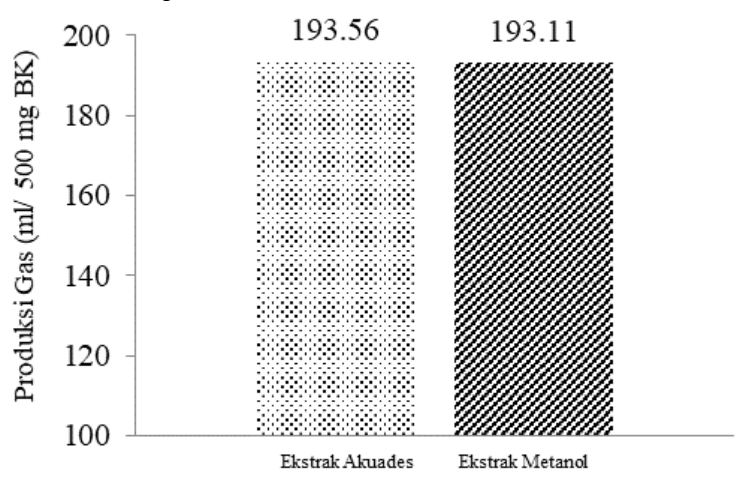

G0a0mbar 1. Nilai Potensi Produksi Gas (b) Pakan dengan Penambahan Ekstrak Buah Mengkudu Menggunakan Jenis Pelarut yang Berbeda

Nilai b erat kaitannya dengan ketersediaan energi berupa VFA yang dihasilkan selama proses fermentasi pakan. Semakin tinggi nilai $b$, maka semakin banyak potensi bahan organik yang mampu didegradasi oleh mikroba rumen untuk menghasilkan VFA. Nilai c merupakan nilai laju produksi gas yang menggambarkan dinamika peningkatan produksi gas yang terjadi pada waktu inkubasi 0-48 jam. Produksi gas yang dihasilkan menunjukkan tinggi rendahnya aktivitas mikroba di dalam cairan rumen untuk mendegradasi pakan.

Hasil analisis ragam menunjukkan bahwa tidak terdapat perbedaan $(\mathrm{P}>0,05)$ antara perlakuan pemberian ekstrak buah mengkudu dengan menggunakan akuades maupun dengan menggunakan metanol sebagai pelarut dalam proses ekstraksi terhadap laju produksi gas (c). Rata-rata nilai laju produksi gas (c) pada penambahan ekstrak akuades dan metanol buah mengkudu berturut-turut adalah $0,049 \pm 0,005 \mathrm{ml} / \mathrm{jam}$, dan $0,048 \pm 0,004$ $\mathrm{ml} / \mathrm{jam}$.

\section{Model persamaan regresi antara jumlah protozoa hidup dan produksi gas in-vitro \\ Hasil analisis statistika} menunjukkan bahwa tingkat keeratan (r) antara jumlah protozoa hidup dan produksi gas sebesar 0,30 pada perlakuan penggunaan akuades sebagai pelarut. Pola hubungan antar keduanya berbentuk linier positif dengan persamaan $\mathrm{Y}=2,98 \mathrm{X}-0,07$, sedangkan pada perlakuan akuades sebagai pelarut memiliki nilai $r$ sebesar 0,31 dengan persamaan $\mathrm{Y}=2,93 \mathrm{X}-$ 0,08 , dengan $\mathrm{Y}$ merupakan produksi gas (ml/ $500 \mathrm{mg}$ BK pakan) dan X merupakan jumlah sel protozoa yang hidup (log/ ml cairan rumen).

Berdasarkan hasil analisis regresi menunjukkan bahwa persamaan linier $\mathrm{Y}=2,98 \mathrm{X}-0,07$ dan $\mathrm{Y}=2,93 \mathrm{X}$ - 0,08 antara faktor jumlah protozoa hidup dan produksi gas adalah nyata $(\mathrm{P}<0,05)$. Pola hubungan antara jumlah protozoa hidup dengan produksi gas yang dihasilkan menunjukkan adanya korelasi positif yang ditandai dengan nilai X pada persamaan bernilai positif. 
Pola hubungan tersebut tertera pada gambar 2 dan gambar 3.

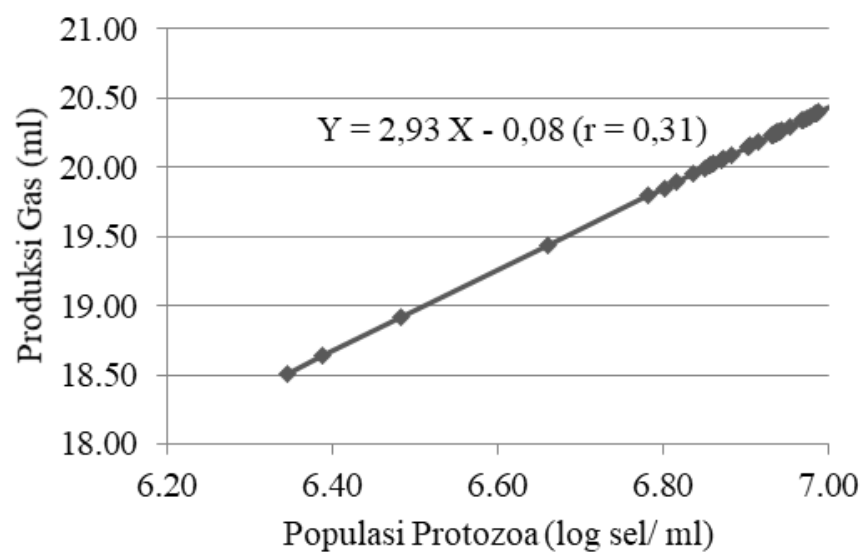

Gambar 2. Nilai Koefisien Korelasi (r), Persamaan Linier serta Korelasi antara Produksi Gas (Y) dan Jumlah Protozoa Hidup (X) dengan Akuades sebagai Pelarut

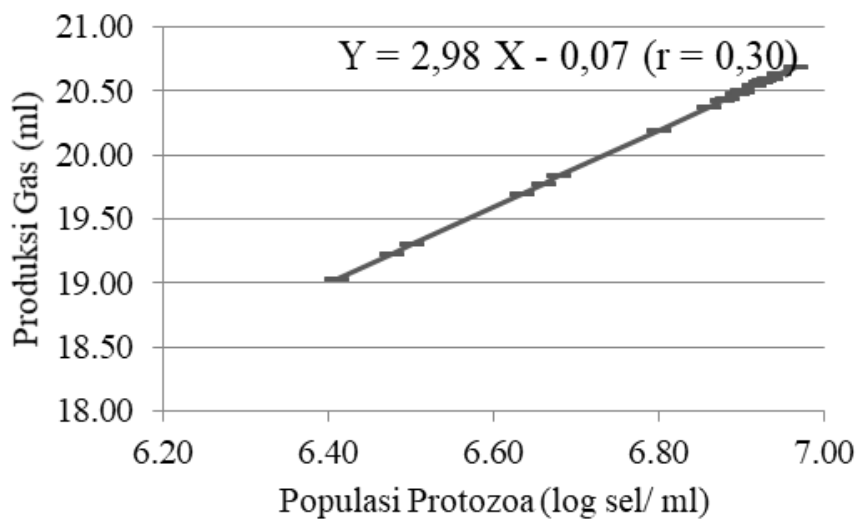

Gambar 3. Nilai Koefisien Korelasi (r), Persamaan Linier serta Korelasi antara Produksi Gas (Y) dan Jumlah Protozoa Hidup (X) dengan Metanol sebagai Pelarut

Berdasarkan persamaan tersebut diketahui bahwa terdapat korelasi positif antara jumlah protozoa hidup dengan produksi gas total. Korelasi positif ditandai dengan nilai $\mathrm{X}$ pada kedua persamaan bernilai positif. Korelasi positif bermakna jika terjadi peningkatan jumlah sel protozoa hidup dalam cairan rumen, maka akan diikuti dengan kenaikan produksi gas hasil fermentasi. Pernyataan ini sesuai dengan hasil penelitian Sclegel (1994) dan Jouany (1991) dalam Masruroh dkk. (2013) bahwa populasi protozoa rumen berbanding lurus dengan produksi gas yang dihasilkan.

\section{KESIMPULAN}

Penggunaan metanol sebagai pelarut dalam proses ekstraksi buah mengkudu memberikan respon terbaik untuk menurunkan presentase viabilitas protozoa rumen dan produksi gas total secara in-vitro.

\section{SARAN}

Perlu dilakukan penelitian lanjutan dengan pengukuran produksi gas metana pada masing-masing perlakuan sebagai salah satu variabel dan komposisi masing-masing gas hasil fermentasi.

\section{DAFTAR PUSTAKA}

Arora, S.P. 1995. Pencernaan mikroba pada ruminansia. cetakan kedua. Gadjah Mada University Press, Yogyakarta

Astarina, N.W.G., Astuti, K.W., dan Warditiani, N.K. 2013. Skrining fitokimia ekstrak metanol rimpang bangle. Jurnal Farmasi Udayana 2 (4): 1-6. ISSN: 2301-7716

Dinata, D.D., Widiyanto, dan Pujaningsih, R.I. 2015. Pengaruh suplementasi dan proteksi minyak biji kapuk terhadap fermentabilitas ruminal rumput gajah pada sapi secara in-vitro. Agripet 15 (1): 46-51

Herdian, H., Istiqomah, L., Febrisiantosa, A., dan Setiabudi, D. 2011. Pengaruh penambahan daun Morinda citrifolia sebagai sumber saponin terhadap karakteristik fermentasi, defaunasi protozoa, produksi gas dan metana cairan rumen secara in- 
vitro. Jurnal Ilmu Ternak dan Veteriner (16): 98-103

Kurniawati, A. 2007. Teknik produksi gas in-vitro untuk evaluasi pakan ternak: volume produksi gas dan kecernaan bahan pakan. Jurnal Ilmiah Aplikasi Isoptop dan Radiasi. ISSN: 1907-0322

Lamid, M., Nugroho, T.P., Chusniati, S., dan Rochiman, K. 2011. Eksplorasi bakteri selulolitik asal cairan rumen sapi potong sebagai bahan inokulum limbah pertanian. Jurnal Ilmiah Kedokteran Hewan 4 (1): 37-42

Makkar, H.P.S, Blummel, M., and Becker, K. 1995. Formation of complexes between polyvinyl pylory dones on pholyethilene glycoles and tanin and their implication in gas production and true digestibility in-vitro techniques. Journal of Nutrition Britania 73:893-913

Masruroh, S., Prayitno, C.H., dan Suwarno. 2013. Populasi protozoa dan produksi gas total dari rumen kambing perah yang pakannya disuplementasi ekstrak herbal secara in-vitro. Jurnal Ilmiah Peternakan 1 (2): 420-429.

Menke, K.H., Raab, L., and Salewski, A. 1979. The estimation of the digestibility and metabolizable energy content of rumninant feedstuffs from the gas production when they are incubated with rumen liquor in vitro. Journal of Agriculture Science Cambridge (92): 217-222

NRC. 2001. Nutrient requirements of dairy cattle: subcomitte on dairy cattle nutrition. Commite on Animal Nutrition, National Research Council, National Academy Press, Washington D.C.
Ogimoto, K., and Imai, S. 1981. Atlas of Rumen Microbiology. Japan Science. Societes Press, Tokyo.

Oleszek, W.A. 2000. Saponins. CRC Press LLC

Rianto, E., Haryono, E., dan Lestari, C.M.S. 2006. Produktivitas domba ekor tipis jantan yang diberi pollard dengan aras berbeda. Seminar Nasional Teknologi Peternakan dan Veteriner

Satwadhar, P.N., Desphande, H.W., Hashmi, S.I., and Syed, K.A. 2011. Nutritional composition and identification of some bioactive components in morinda citrifolia juice. International Journal of Pharmacy and Pharmaceutical Sciences 3(1): 58-59. ISSN: 09751491

Thalib, A., Widyawati, Y., dan Hamid, H. 2004. Uji efektivitas isolat bakteri hasil isolasi mikroba rumen dengan media asetogen sebagai inhibitor metanogenesis. Jurnal Ilmu Ternak dan Veteriner 9 (4): 233-238

Valli, G., and Murugalakshmi, M. 2014. Isolation, preliminary phytochemical and antibacterial activity studies of the constituents present in ethanol extract of manjanathi fruits. International Journal of Innovative Research in Science, Engineering and Technology 3 (3): 9940-9946 ISSN: 2319-8753

Wahyuni, I.M.D., Muktiani, A., dan Christianto, M. 2004. Penentuan dosis tannin dan saponin untuk defaunasi dan peningkatan fermentabilitas pakan. Jurnal Ilmu dan Teknologi Peternakan 3 (3): 133-140 